\title{
REGIONALISM AND DISTRIBUTION OF POWERS IN FEDERAL STATES
}

\section{Gulnara R. Shaikhutdinova}

Doctor of Legal Science, Master of Laws (LL.M), Professor, Department of International and European Law. Kazan (Volga Region) Federal University.

Address: 18 Kremlevskaya St., 420008 Kazan, Russian Federation.

E-mail: ildar_sh@mail.ru

\begin{abstract}
The purpose of this article is to analyze the influence of regionalism on the mechanism of distribution of powers between the levels of authorities within the federal states. The objectives of the research are:

- $\quad$ to identify and classify the different models of distribution of powers in modern federations, based on the examples of Switzerland, Belgium and the Russian Federation;

- $\quad$ to determine the principles of distribution of powers;

- $\quad$ to find the most effective models of distribution of powers;

- $\quad$ to make practical recommendations on distribution of powers for the Russian federal system. method.

System analysis and comparative analysis methods were widely used as well as a didactic

The result of the research: Regionalism determines the particular model of distribution of powers in modern federations; the regions initiate the principles of distribution of powers such as subsidiarity and enhanced cooperation.

Conclusions:

- $\quad$ the modern federal settings demonstrate three models of distribution of powers depending on the role of the regions (constituent units) within the federation;

- $\quad$ the principle of subsidiarity is proved to form the basis for the most effective models of distribution of powers in modern federations;

- $\quad$ the agreements between the constituent units of federations and the federal center and the units are the result of implementation of the principle of enhanced cooperation.
\end{abstract}

Keywords: federalism, regionalism, regionalization, distribution of powers, subsidiarity, enhanced cooperation.

Citation: Shaikhutdinova, G.R. (2016). Regionalism and Distribution of Powers in Federal States. Public Administration Issues, no 5 (Special Issue, electronic edition), pp. 138-149 (in English).

\section{Introduction}

In the coming decades, regions will determine the future of federations worldwide: they will play a decisive role in ensuring the effectiveness of federations being understood as an absence of conflict and the cooperation of a federal 
center and constituent units, and federal-regional relationships based on mutually agreed distribution of powers according to principles of subsidiarity and enhanced cooperation.

This article is aimed at demonstrating that regionalism, taking place in federal states and in states with a certain degree of decentralization and autonomy, is becoming a worldwide phenomenon, having its cradle in Western Europe and spreading widely to the Americas and Eastern Europe, especially to the territory of the Russian Federation. In federal states, regionalism influences the distribution of powers between a federal center and constituent units, shaping the particular models of distribution of powers. Regions initiate the principles of distribution of powers such as subsidiarity and enhanced cooperation.

The principle of subsidiarity is a constitutional principle in a number of federations such as Switzerland, Germany, and Austria. It means that a federation should undertake action only if constituent units cannot exercise it efficiently and achieve the relative goal. More powers should be allocated to the layers of power under the federal level, thus the action is brought nearer to the citizen. A federation comes into play in exclusive circumstances; its role is subsidiary to those of the units.

The principle of enhanced cooperation in the federal context means the treaty arrangements among constituent units (the horizontal dimension) and between a federal center and constituent units (the vertical dimension) in further widening and deepening mutual cooperation, going far beyond the margins established in the relevant federation. It is a constitutional principle in a number of federations, such as Germany, Switzerland, the USA and the Russian Federation.

\section{Regionalism as a prerequisite for distribution of powers}

In every given country, regionalism has different roots: economical, ethnic (Keating, Wilson, 2014, p. 840), cultural, linguistic (Keating, 1998). Regionalism develops both in unitary and federal states. Irrespective of the form of a state where it evolves, regionalism inevitably leads in this form or another to the question of distribution of powers between central government and regions. This is the question of stability or instability of a federal state (Farukshin, 2001, p. 98). Each country establishes its own mechanism of distribution of powers using different basic principles. In spite of the fact that in different areas regionalism is fostered by various driving forces and has specific roots, the process is comparable and has common legitimacies.

Before entering into explanations on the topic, it is expedient to clarify the definitions which will be used in this article. In European nation-states, we observe both regionalism and regionalization. In spite of one root of these two notions, there is a clear distinction between them (Loughlin J., Kincaid J., Swenden W., 2013).

Michael Keating treats regionalization as a nation-state initiative to reconstruct internal state structure and pass down [italic is mine - G. Sh.] some of the governmental functions to territorial entities. This reduces the burden of vast 
governmental tasks and brings decision-making closer to the citizens, thus making the whole system more effective. It is the source where the principle of subsidiarity is rooted.

Regionalism is inspired by territorial entities and the driving forces behind it are economic and/or ethnical and cultural endeavors of regional elites and the population. Regions claim not only mere execution of federal decisions, but also the right to make decisions of their own and execute them by their own means.

"The region is a contested territory and there is continuing tension between the strategy of regionalization as state policy, and regionalism as a movement from below" (Loughlin, 1994).

In order to access the role of regionalism in shaping the models of distribution of powers we shall refer to the case studies of Germany, Switzerland and the Russian Federation.

\section{Distribution of powers in different federal settings}

\section{Switzerland}

Switzerland is composed of 26 cantons - constituent units of federation, where seventeen cantons are German-speaking, four cantons are Frenchspeaking, one canton is Italian-speaking, three cantons are bilingual (Germanand French-speaking) and one canton is trilingual (German-, Romansh- and Italian-speaking). Switzerland is a centripetal federation: it was formed of formerly independent states. This circumstance defines the very essence of the Swiss federation and the mode of distribution of powers. The cantons possess all the rights of a sovereign, with the exception of those which they delegated to the federal center. Thomas Fleiner writes: "the cantons have the residual and original [italic is mine - G. Sh.] power" (Fleiner, 2000, p. 17). Because at supra level, the Confederation is a new body, which originated from the sovereign cantons, its powers are precisely enumerated in the Swiss federal constitution. Cantonal competences are not listed (with mere exceptions), because it is presumed that the cantons possess all the rights inherent to the sovereign and these rights are evident.

This principle is laid down in Article 3 of Swiss constitution, which reads as follows: "The Cantons are sovereign insofar as their sovereignty is not limited by the Federal Constitution: they exercise all rights which are not transferred to the Confederation" (Constitution of Switzerland, 1999). Under this provision "all the powers of the federal government have to be spelled out in the federal Constitution" (Fleiner, 2000, p. 17). The Constitution of 1874 contained the provision which stipulated that the federal government could only claim competencies by interpreting the relevant articles of the Constitution. This provision was changed in the new Constitution of 2000. Article 42 of this states:

"(1) The Confederation shall accomplish the tasks which are attributed to it by the Constitution.

(2) It shall assume the tasks, which require uniform regulation [italic is mine G. Sh.]". 
Federal powers. A number of articles of the Swiss constitution define exclusive powers of the Confederation. As a rule, in the text of the Constitution the term "a federal matter" is used. Most of the federal powers are in the legislative sphere. These are matters which require uniform regulation. We find them in Article 54 (foreign relations), Article 58 (3) (the use of the army), Article 60 (1) (legislation on the military and on the organization, the instruction, and the equipment of the army), Article 61 (1) (legislation on civil defense), Article 87 (legislation on rail traffic, cable cars, navigation, aviation, and space travel), etc.

Cantonal powers. One of the major powers of cantons is the right to have their own constitutions, which is provided for in Article 51 of Swiss constitution. The cantonal constitution must be approved by the people, and must be subject to revision if a majority of the people so requires.

As Flora Goudappel points out, "exclusive powers of the Cantons are only mentioned in the federal Constitution when they are an exception to exclusive powers allocated to the Confederation"' (Goudappel, 1997, p. 45). For example, Article 54 (1) defines international relations as a federal matter, while Article 55 (1) and (3) determines the rights of cantons in this sphere: "to participate in the preparation of decisions of foreign policy, which concern their powers or their essential interests", and "to participate in international negotiations as appropriate, when their powers are concerned". It was fairly noticeable in the scientific literature on constitutional law that it is difficult to provide for a list of possible exclusive powers of cantons (Ibid., p. 47).

Thomas Fleiner mentioned that with regard to the actual distribution of powers between the Confederation and cantons, the new Constitution does not contain any important changes. One of the major aims of the new Constitution was to give the actual system a modernized wording, but to avoid any significant amendments that would dramatically change the balance of powers in Switzerland (Fleiner, 2000, p. 18).

The principle of subsidiarity is clearly evident in the text of the Swiss Constitution. It is presumed from Article 3 - "They [cantons - G. Sh.] exercise all rights that are not vested in the Confederation"; and is expressly stated in $\mathrm{Ar}$ ticle 5a2 "Subsidiarity": "The principle of subsidiarity must be observed in the allocation and performance of state tasks". The provision granting all rights with the exception of those vested in the Confederation to the cantons brings the decision-making closer to the citizen. The Confederation intervenes in exceptional cases; its role is subsidiary to those of the cantons.

\section{Belgium}

Belgium represents the most recent and the most complicated example of federal-type arrangement in Europe. Formally, the Belgian federation was formed in 1993, when changes were introduced into the Belgian Constitution. Federalization of Belgium was the result of regional movement, the active position of communities and regions and their endeavors to gain more powers. The Constitution leads with the declaration of Belgium: "a Federal state made up of communities and regions" (Article 1 of the Constitution of Belgium). Bel- 
gium consists of three communities and three regions (articles 2 and 3 of the Constitution of Belgium) (Constitution of Belgium, 1993).

The Belgian constitutional system follows the rule of assigning one power to one entity (Veys, 1993, p. 135) and distributes mainly exclusive powers. Different systems of distribution of powers are used in cases of communities and regions.

The powers of communities are provided for in Articles 127, 128 and 128 of the Constitution.

According to Article 127 (1) the responsibilities of the French and Dutch Community Councils are:

1) cultural issues;

2) education, with the exception of:

a) the determination of the beginning and the end of mandatory solidarity;

b) minimum standards for the granting of diplomas;

c) attribution of pensions;

3) inter-community co-operation, in addition to international cooperation, including the drafting of treaties for those matters described in (1) and (2). According to Article 129 of the Constitution, the French and Dutch Community Councils exercise legislative power, excluding the federal legislator, on the use of language for:

1) administrative matters;

2) education in those establishments created, subsidized, and recognized by public authorities;

3) social relations between employers and their personnel, in addition to corporate acts and documents required by law and by regulations.

Article 128 of the Constitution provides for legislative power of the French and Flemish Community Councils in personal issues. Such personal issues are to be determined in the special law adopted by majority vote, provided for in Article 4 (2) of the Constitution. Such special law - the Special Institutional Reform Act - provides for the powers of the French and Dutch Community Councils to issue legislation in the sphere of medical care, the aid to families and children, etc.

According to the Article 130 of the Constitution the German Community has powers in:

1) cultural issues;

2) personal issues;

3) education, within the limits established by Article 127, $₫ 1$, par. 1, 2;

4) inter-community co-operation, in addition to international cooperation. including the conclusion of treaties, for issues described in 1,2 and 3.

The peculiarity of the Belgian federal system is the existence of a double set of federated entities. Along with communities, there are regions. The powers of the regions are not listed in the Constitution. We find only a reference provision in Article 39, which states that the regional bodies shall have the power to manage matters which are determined by law, with the exception of those referred to in Articles 30, 127 and 129, within the jurisdiction and according to the manner established by law. Such law is the Special Institutional Reform Act of 1980, its Article 6 determines the powers of the regions: water management, town and country planning, waste products, etc. 
Community and regional governments enjoy powers in the international sphere. As provided for in Article 167 (3) of the Constitution, they conclude, in matters that concern them, treaties regarding matters that are in the scope of the responsibilities of their Councils.

We can conclude that Belgian communities were created in order to fulfil cultural, linguistic and educational tasks, while Belgian regions were created with the purpose of urban development. The range of powers of the communities and regions is rather narrow.

For the purposes of the present research at least two major characteristics of the Belgian federation are important:

1) the multi-ethnic character of the country, uniting three major linguistic groups: French, Dutch and German;

2) the fact that the Belgian federation was formed of a unitary state.

The existence of three linguistic groups in Belgium and the necessity to ensure peaceful and cooperative relations between them represents a difficult task for the Belgian federation.

The fact that Belgium was formed of a former unitary state foreordained the basic principle of distribution of powers between the federal center and communities and regions. The Belgian constitutional system has as its core the rule that all power originates from the federal center, i.e. the federation, as far as the federation is a successor of the former unitary state. Following this logic, the constitution of Belgium focuses on a clear and detailed description of the powers allocated to the communities and regions and not on those allocated to the federal center, because it is presumed that the federal center possesses all original sovereign power and there is no need to clarify it. Here we see the same logic as in the Swiss constitutional system but find it "up-side down". Switzerland was formed by independent slates, which are considered to have their original sovereign power and the powers of cantons as successors of these formerly independent slates are not regulated in the Constitution of Switzerland (with some exceptions). On the contrary, the powers of the "new" entity - the Confederation - are determined precisely in the Constitution.

\section{Russian Federation}

The collapse of the Soviet Union in 1991 gave a new impulse to the development of regionalism in the Russian Federation and other assignee-states. Regionalism in Russia was rooted in the increase of self-consciousness of titular nations in the former autonomous republics and their demands for autonomy, sometimes in extreme forms, such as claims for sovereignty and self-determination in the form of creation of an independent state. Titular nations often relied on the rich economic resources they have on their territories, such as oil and gas or powerful defense-industry complex enterprises left after the Soviet era, as an economic basis of sovereignty. The most powerful among the constituent units of Russia - the autonomous republics - declared state sovereignty right after the Soviet Socialist Republics of the former USSR. The first into this row was the Republic of Tatarstan followed by the other nineteen. The period of declaration of state sovereignty by the Russian regions was called the parade of sovereignties. Some of the autono- 
mous republics were planning to increase their status to that of the union republics and among the latter to become co-founders of the Commonwealth of Independent States (CIS). For example, after its declaration of state sovereignty the Republic of Tatarstan was a party in negotiations in Belovezhskaya Pusha, but did not succeed. The period from 1992 to 1999 was a time of active regional movement in the Russian Federation. It was even more than just regionalism; it was the decade of the formation of completely new state structure, which can be characterized as federal with certain confederal elements. At the end of the 20th century, the Russian Federation consisted of 89 constituent units: twenty-one national republics, six krai, forty-nine oblasti, two cities of federal importance - Moscow and St. Petersburg, one Jewish Autonomous oblast and ten autonomous okruga.

The distribution of powers mechanism was multi-fold and regulated in: 1) the federal constitution; (2) treaties on delimitation of authorities between the bodies of state power of the Russian Federation and the bodies of state power of the constituent unit; (3) constitutions (ustavi) of the constituent units of the Russian Federation; (4) the Federative Treaty of 1992 (actually three treaties); (5) federal laws.

Federal Constitution. The system of distribution of powers in Russian constitutional law comprises different types of powers: exclusive powers of the federal center, exclusive powers of the constituent units, shared powers of the federal center and the constituent units (joint competence), namely framework legislation. The above-mentioned types of powers are provided for in the federal constitution (Articles 5, 71. 72. 73. 76). In practice, concurrent powers exist, but they are not mentioned in the Constitution. These are situations when the constituent units pass legislation on matters of joint competence while the federal center is reluctant to do this. If, however, the federal center finds it necessary to pass federal legislation on the issue of joint competence, it is doing so while not taking into account the provisions led down by the constituent units. The constituent units then have to amend their legislations according to the federal law.

Distribution of powers is provided for in the three articles of the Constitution of the Russian Federation. Article 71 contains the list of exclusive federal powers, such as the adoption and amendment of the Constitution of the Russian Federation and federal laws and supervision over compliance with them, the federal structure and territory of the Russian Federation, etc. Article 72 of the Russian Constitution provides for the list of authorities in joint competence of the Federation and the constituent units. Article 73 of the Constitution of the Russian Federation states that beyond the jurisdiction of the Russian Federation and the powers of the Russian Federation on issues within the joint jurisdiction of the Russian Federation and the constituent units of the Russian Federation, the constituent units of the Russian Federation shall exercise the entire spectrum of state power. This provision was partly clarified in a small number of articles of the Russian Constitution. Article 5 (2) provides for exclusive powers of the constituent units, i.e. the right of the republics to have their own constitutions and legislation and the right of the other constituent units to have ustavi and legislation. Article 76 regulates distribution of powers in the legislative sphere: 
"1. On matters within the joint jurisdiction of the Russian Federation and the subjects of the Russian Federation, federal laws shall be issued and in accordance with them laws and other regulatory legal acts of the subjects of the Russian Federation shall be adopted.

4. Outside of the jurisdiction of the Russian Federation and the joint jurisdiction of the Russian Federation and the subjects of the Russian Federation republics, territories, regions, federal cities, autonomous regions and autonomous areas shall effect their own legal regulation, including the adoption of laws and other regulatory legal acts.

5. Laws and other regulatory legal acts of the subjects of the Russian Federation may not contravene federal laws adopted in accordance with parts 1 and 2 of this Article. In the event of a contradiction between a federal law and any other act issued in the Russian Federation, the federal law shall apply" (Constitution of the Russian Federation, 1993).

Treaties on delimitation of authorities between the bodies of state power of the Russian Federation and the bodies of state power of the constituent unit. The possibility to conclude such treaties is provided for in Article 11 (3) of the federal Constitution: "The scopes of authority and powers of the bodies of state authority of the Russian Federation and the bodies of state authority of the subjects of the Russian Federation shall be delimited under this Constitution, Federal and other Treaties on the delimitation of scopes of authority and powers [italic is mine - G. Sh.]". The constituent units, above all the republics, of the Russian Federation were not satisfied with a distribution of powers pattern set down in the federal constitution due to its ambiguity. The Republic of Tatarstan was the first to propose the federal center to sign the "Treaty on delimitation of jurisdictional subjects and mutual delegation of powers", which was signed on February 15, 1994 (Treaty on delimitation of jurisdictional subjects and mutual delegation of powers, 1994). The example of Tatarstan was followed by 48 constituent units of the Russian Federation, which concluded the treaties of distribution of powers with the federal center (but not on mutual delegation of authorities).

However, the federal trend in the Russian history of the 90s was narrowed by the campaign on the harmonization of legislation of constituent units with the federal legislation. The treaties on distribution of powers were in force for the period specified in the respective texts. The treaty between Moscow and Kazan was in force for 10 years and in 2007 took the form of Federal law (Federal law N 199-Ф3, 2007) with a much more modest list of distributed powers.

These vertical treaties between the federal center and the constituent units demonstrated the tendency of enhanced cooperation. The provision of Article 11 (3) of the Constitution of the Russian Federation proves the existence of the constitutional principle of enhanced cooperation between the federal center and constituent units in the Russian Federation. Such treaties give an interpretation of the Article 73 of the Constitution of the Russian Federation which forms a gray area, leading to multiple misunderstandings and discussions; filling the legal gap in defining the powers of constituent units. The Russian Constitution clearly lists the exclusive powers of the federal center and the shared powers 
of the federal center and the constituent units. However, it is silent about the list of powers of constituent units; this can be formed only residually. In our opinion, this residual principle decreases the efficiency of the mechanism of distribution of powers as well as the efficiency of the federal system in Russia. The vertical treaty arrangements between the federal center and the constituent units clarify the delicate matter of power distribution, and prevent possible conflicts of competencies and tension between different layers of power within the federal system, thus fostering and enhancing federalism. These vertical treaty arrangements together with treaties among the constituent units themselves reflect the principle of enhanced cooperation in a federal system.

Nowadays in Russia, the distribution of powers mechanism has changed from multi-fold to practically constitutional. The constituent units are reluctant to conclude treaties with the federal center while the role of the constitutions (ustavi) of the units and the federal laws on this matter is small. This is the situation where "the sharing of powers between the federal government and the state and provincial governments often evolves to a point at which federal powers became exclusive but state/provincial powers remain shared" (Majeed A., Watts R., Brown D., 2006: 4).

\section{Major results}

\section{Consequences of regionalization and regionalism on the state structure}

It is likely that regionalization has a minor impact on the state structure, especially on the form of government. As a rule, a state is unwilling to change the state of affairs, it merely delegates certain powers to a lower level of government. Even if the new entities are established, it is done for the purpose of fulfilling new tasks on a certain territory and has nothing to do with the form of government.

On the contrary, regionalism as an initiative "from below" may have an impact on the form of state structure. In its extreme form, it can lead to the establishment of a federal form of government. Some authors presume that regionalism loses its final goal if it does not lead to federalism. Jansen states that it has been shown that regionalism misses its aim if it does not follow its own dynamical impetus, i.e. if it is not followed by federalization which transfers, step by step to the regions, the responsibility for their own affairs and their co-responsibility for the federal state (Jansen, 1999: 202). However, regionalism does not necessarily lead to federalism, it can end up somewhere between a unitary and federal form of government.

In federal states, regional demands in economic, political, national or ethnic spheres take a form of the claims for competencies and financial resources to carry out these competencies. These claims are addressed to the federal government, and it is a party that has to share competencies.

\section{The influence of regionalism on the model of distribution of powers}

There appears to be some logic behind a clear definition of powers of the entity, which was not originally in place, and which originated out of the other or by the will of others. Therefore, in Switzerland we have formerly independent 
entities which formed the federation. These entities were sovereign then and are sovereign now, which means they possess the range of competences usually attributed to the sovereign. The cantons then formed the federation and delegated a number of their powers to it. The new sovereign's competence is clearly defined in the federal Constitution. Such legal regulation fosters progressive and effective development of a federation out of former independent units.

In the Russian Federation we find the opposite. The federation was formed based on a unitary state, which means the new entities were the constituent units, not the federation. In this process of formation of a federation, the powers are transferred from the center to the constituent units, i.e. from full sovereign to the entities, sovereignty of which is under dispute. In the Constitution of the Russian Federation, we do not find any provision on the sovereignty of constituent units. It can be theoretically drawn out of the provision of Article 5(4), where one type of constituent unit - the republics - are modestly, in brackets, called "states".

\section{Regionalism in multiethnic states}

The history of state governance justifies the thesis that it is very difficult to manage multi-ethnic polities. Multi-ethnic societies represent a challenge for governments due to a number of peculiarities: cultural, linguistic, religious and others. In addition to the primary task of achieving effective governance, what also emerges is the necessity to harmonize inter-ethnic relations, satisfy the demands of ethnic minorities and even fit minorities' claims for self-governance into the realm of state structure.

Ethnic challenges seem even greater in federal states with a clearly defined ethnic component. These countries face both globalization and localization. Examples of older effective ethnic federations exist, such as Switzerland, as well as recently shaped ethnic federations such as Belgium. In the Russian Federation, the ethnic component appears to be a defining factor.

\section{Conclusions}

In terms of state structure, the major consequence of regionalism is the distribution of powers between the federal center and the constituent units.

In federations, where the role and voice of constituent units is strong, more powers are granted to them. If the degree of activity of constituent units is low, a federal center reserves more powers while the powers of constituent units are listed residually and not even listed in the federal constitution and federal laws. The above three case studies demonstrate three models of distribution of powers in federal states:

1) with clearly defined federal powers and residual powers of constituent units (Switzerland);

2) with clearly defined powers of constituent units and residual powers of a federal center (Belgium);

3) with clearly defined powers a federal center, shared powers of a federal center and constituent units and powers of constituent units themselves (the Russian Federation in 1994-2004). 
As the case studies show, the distribution of powers models are formed based on two principles: the principle of subsidiarity and the principle of enhanced cooperation. The principle of subsidiarity helps to improve the effectiveness of a power distribution mechanism in federal states as well as the effectiveness of a federation itself. It brings the decision-making closer to the citizen, to the lower levels of government. It is evident that from its high position a federal center is unable to realize all the local problems of a population of particular constituent units; the lower levels of government are closer to revealing and understanding these problems. The principle of subsidiarity is proved to form the basis for the most effective models of distribution of powers, such as in Switzerland. It is not a constitutional principle in the Russian Federation, but it should be considered as such and used in conjunction with the principle of enhanced cooperation.

The principle of enhanced cooperation is an important constitutional principle in a number of federations, such as the Russian Federation, Germany and Austria. In the case of the Russian Federation, it was the basis for the model of distribution of powers which existed in 1994-2004. This model was distinguished by its legal regulation of exclusive powers of constituent units in the treaties on delimitation of authorities between the federal center and constituent units as an addition to those of a federation and shared powers of a federation and the units. As a result, the gap in the legal regulation of the units' powers in the federal constitution was filled. Since the treaty between the federal center and the Republic of Tatarstan of 2007 is the only existing example, we can conclude that constituent units are reluctant to use the mechanism of enhanced cooperation in its vertical dimension.

\section{REFERENCES}

1. Constitution of Belgium, 1993. Available: http://www.wipo.int/wipolex/en/details. jsp?id=11637 (accessed: 14 October, 2016).

2. Constitution of the Russian Federation, 1993. Available: http://www.constitution.ru/ en/10003000-01.htm (accessed: 14 October, 2016).

3. Constitution of Switzerland. Available: https://www.admin.ch/opc/en/classifiedcompilation/19995395/201601010000/101.pdf (accessed: 14 October, 2016). 
4. Goudappel, F.A.N.J. (1997). Powers and Control Mechanisms in European Federal Systems. 14 November, EUR Rotterdam (273 pag.) (Deventer: Gouda Quint).

5. Farukshin, M. (2001). Sravnitelnyi federalism: Uchebnik po spezkursu [Comparative federalism: the Textbook for the course]. Kazan: Izdatelstvo Kazanskogo universiteta.

6. Fleiner, T. (2002). Recent developments of Swiss federalism. The Journal of Federalism, vol. 32, no 2, pp. 97-123.

7. Jansen, T. (1999). Gibt es eine Konzeption der Europaischen Kommission fur die regionale ordnung der Union? (In: Peter Nitschke (ed.) Die Europaische Union der Regionen, Subpolity und Politikender Dritten Ebene). Opladem.

8. Keating, M. (1998). The new regionalism in Western Europe: territorial restructuring and political change. Cheltenham: Edward Elgar.

9. Keating, M. \& Wilson, A. (2014). Regions with regionalism? The rescaling of interest groups in six European states. European Journal of Political Research, vol. 53, no 4, pp. $840-857$.

10. Loughlin, J. (1994). Nation, state and region in Western Europe. In: L. Bekemans (ed.) Culture: Building stone for Europe 2002. Brussels: European Interuniversity Press.

11. Majeed, A., Watts, R. \& Brown D. (2006). Distribution of Powers and Responsibilities in Federal Countries. McGill-Queen's Press - MQUP.

12. Routledge Handbook of Regionalism and Federalism. Edited by: Loughlin J., Kincaid J. \& Swenden, W. Routledge, 2013.

13. Treaty on delimitation of jurisdictional subjects and mutual delegation of powers, signed on February, 15, 1994. Avalable: http://www.kazanfed.ru/en/docum/dogovor/1/ (accessed: 10 December, 2016).

14. Veys, M. (1993). De "exclusiviteit" van de federatief opgedeelde normatieve bevoegdheden: rechtsvergelijkende inzichten. Tijdschrift voor Bestuurswetenschappen en Publiekrecht (T.B.P.), pp. 144-145. 